\title{
Research on the Influencing Factors of Corporate Social Responsibility Disclosure
}

\author{
Kexin Feng1, Xuanzhang Li ${ }^{2}$ \\ ${ }^{1}$ School of Journalism and Communication, Nanjing Normal University, Nanjing, China \\ ${ }^{2}$ Jiangsu Branch, China Guangfa Bank, Nanjing, China \\ Email: 645369266@qq.com
}

How to cite this paper: Feng, K. X., \& Li, X. Z. (2021). Research on the Influencing Factors of Corporate Social Responsibility Disclosure. Open Journal of Social Sciences, 9, 1-11.

https://doi.org/10.4236/jss.2021.93001

Received: February 5, 2021

Accepted: February 26, 2021

Published: March 1, 2021

Copyright $\odot 2021$ by author(s) and Scientific Research Publishing Inc. This work is licensed under the Creative Commons Attribution International License (CC BY 4.0).

http://creativecommons.org/licenses/by/4.0/ (c) (i) Open Access

\begin{abstract}
Based on the theoretical analysis, this paper empirically analyzes the influence of media attention and other factors on the level of corporate social responsibility disclosure based on the panel data of Chinese A-share listed companies from 2013 to 2017. The results found that: goodwill, core management turnover, and financing constraints all have a significant negative correlation with corporate social responsibility disclosure. Media attention has a significant positive impact on the level of corporate social responsibility disclosure. Market competitive position has no significant impact on corporate social responsibility disclosure. This paper suggests that enterprises should be encouraged to take social responsibility, incorporate disclosure of social responsibility information into corporate culture, further strengthen corporate social responsibility awareness, and improve social responsibility information disclosure mechanism.
\end{abstract}

\section{Keywords}

Corporate Social Responsibility (CSR), Information Disclosure, Media Attention

\section{Introduction}

Corporate social responsibility (CSR) refers to that enterprises not only create profits and bear legal responsibilities to shareholders and employees, but also bear responsibilities to consumers, communities and the environment (Huang et al., 2019). At present, the disclosure of social responsibility information has become the active choice of many enterprises (Zhang, Cai and Ni, 2019). However, there are great differences between different enterprises in terms of the specific content, frequency and degree of disclosure. 
Existing studies have roughly divided the factors that cause the above differences into two categories: external factors and internal factors (Gillan, Koch and Starks, 2021). The former mainly includes media attention (Yu and Chi, 2021), laws and systems (Yuan, 2020), and the latter mainly includes the enterprise's business scale (Gu, Guo and Wang, 2020), ownership structure (Li and Zhang, 2017), profitability (Nan and Sun, 2020), etc. These studies will provide a rich analytical perspective for this paper. However, on the whole, there are still some shortcomings in the existing research on Chinese enterprises, which are mainly reflected in: First, among the Chinese enterprises that disclose social responsibility reports, one part is the enterprises that must disclose social responsibility reports because of the rules proposed by the exchange, and the other part is the enterprises that voluntarily disclose social responsibility reports. Existing research rarely separates these two forms. Second, it is generally believed that one of the main purposes of disclosing social responsibility information is to enhance corporate image, and corporate image will significantly affect corporate goodwill, but few people pay attention to the impact of corporate goodwill on its social responsibility information disclosure. Third, the compilation and disclosure of social responsibility information requires a certain economic cost, which will affect the degree of financing constraints of enterprises. However, the existing studies on how corporate financing constraints affect the disclosure of social responsibility information are inconsistent. Fourth, in terms of the relevant research on how media attention affects the disclosure of social responsibility information, some scholars focus on paper media and some scholars focus on network media. However, there are few studies that comprehensively consider the influence of paper media and network media. Our study will try to further enrich the existing results from the above four aspects.

In addition to this part, the structure of the rest of this paper is as follows: Firstly, from the aspects of goodwill, core management turnover, financing constraints, market competitive position and media attention, this paper analyzes its impact on corporate social responsibility disclosure in theory one by one and puts forward research hypotheses accordingly; Secondly, variable design, data selection and model construction; Again is the measurement test process and results of the research hypothesis; Finally, conclusions and recommendations.

\section{Theoretical Analysis and Research Hypothesis}

Existing studies have focused on the impact of media attention, internal characteristics of the enterprise and other factors on corporate social responsibility information disclosure, but most of them are empirical studies. This part will first theoretically analyze the influence mechanism of each factor and put forward research hypotheses accordingly.

\subsection{The Impact of Goodwill on Corporate Social Responsibility Disclosure}

Goodwill represents that an enterprise can obtain a higher level of excess profit- 
ability than the same industry in a long period of time, which will directly affect the ability of the enterprise to obtain the resources needed for development. On the one hand, the recognition of goodwill assets will enhance the creditors' confidence in the future development of the enterprise and reduce the creditors' expectations of the risks they may face in the future, which helps to reduce the debt financing cost of the enterprise (Xu, Zhang and Liu, 2017). On the other hand, the reasonable expectation of the external investors for the enhancement of corporate profitability resulting from the recognition of corporate goodwill will respond to the capital market, and even cause investors' overreaction in the capital market (Yang, Song and Feng, 2018). The high valuation brought by these reactions provides convenience for the refinancing in the future. In other words, the recognition of goodwill improves the ability of enterprises to obtain resources, so the motivation of enterprises to disclose social responsibility information will be reduced, and the level of social responsibility information disclosure will decline. In addition, for enterprises with high goodwill valuation, the focus of their work is likely to be on the integrated management of enterprises and the resolution of potential risks, and the corresponding ability to participate in social responsibility-related activities may decline. Therefore, this paper puts forward the following hypotheses:

Hypothesis 1: the higher the goodwill valuation, the lower the level of corporate social responsibility disclosure.

\subsection{The Impact of Core Management Turnover on Corporate Social Responsibility Disclosure}

Whether corporate social responsibility or disclosure of social responsibility information is a long-term strategy for managers. The positive impact of this strategy on enterprises and individuals cannot be reflected in a short time. For enterprises with core management turnover, new managers will generally allocate limited resources to transactions that can be effective in the short term or have high certainty (Tseng and Demirkan, 2021). When facing the pressure of being replaced, the outgoing executives often ignore the long-term strategy of the enterprise, and even increase their in-service income by sacrificing the future interests of the enterprise (Gillan, Koch and Starks, 2021). It can be seen that the disclosure of corporate social responsibility information is far less important than personal interests or the short-term performance of the enterprise at the special time point of management turnover, whether for the outgoing executives or the successor executives. Therefore, this paper puts forward the following hypotheses:

Hypothesis 2: when the core managers change, the level of corporate social responsibility disclosure will be lower.

\subsection{The Impact of Financing Constraints on Corporate Social Responsibility Disclosure}

In theory, the incremental information brought by corporate social responsibili- 
ty disclosure can improve the understanding of creditors and investors to the company, help them make a more comprehensive evaluation of the enterprise, and then reduce the financing constraints. However, in practice, the financing constraints of some Chinese enterprises may not be the liquidity constraints caused by market competition, but depend on the financing channels and government relations of enterprises (Deng and Zeng, 2014). Under this mechanism, large enterprises in a dominant position in the market and enterprises with good government relations will be more likely to obtain financing. Accordingly, financing constraints will be low. When facing higher financing constraints, these enterprises may not alleviate financing constraints by disclosing corporate information including social responsibility information. Therefore, this paper puts forward the following competitive hypothesis:

Hypothesis 3-1: the higher the degree of financing constraints, the higher the level of corporate social responsibility disclosure.

Hypothesis 3-2: the higher the degree of financing constraints, the lower the level of corporate social responsibility disclosure.

\subsection{The Impact of Market Competitive Position on Corporate Social Responsibility Disclosure}

Disclosure of social responsibility information itself also costs a certain amount For those enterprises that are in a weak position in the market, it is obviously not as good as putting resources into daily production and operation. Enterprises with competitive advantages not only have the ability to fulfill social responsibility and disclose social responsibility information, but also want to transmit signals to stakeholders through this kind of information disclosure (Zhang, Cai and $\mathrm{Ni}, 2019$ ), so the quality of social responsibility information disclosure is naturally higher. Therefore, this paper puts forward the following hypotheses:

Hypothesis 4: the higher the market competitive position, the higher the level of corporate social responsibility disclosure.

\subsection{The Impact of Media Attention on Corporate Social Responsibility Disclosure}

The more media attention an enterprise has, the more frequently it appears in the public eye, and the more transparent the company is. On the one hand, when the media carries out positive reports on enterprises, it will establish a positive image for enterprises and bring benefits to enterprises, form incentives for enterprises and continuously disclose high-quality social responsibility reports. On the other hand, negative media reports will bring great pressure to enterprises. In order to restore their image, enterprises will choose to increase investment in the field of social responsibility and take the initiative to disclose social responsibility information (Yu and Chi, 2021). Therefore, whether the media reports on enterprises are positive or negative, or neutral, it will promote enterprises to disclose social responsibility information. Therefore, this paper puts forward the following hypotheses 
Hypothesis 5: the higher the degree of media attention, the higher the level of corporate social responsibility disclosure.

Among the key factors of the above five hypotheses, the first three focus on corporate internal factors, the fifth belongs to external factors, and the fourth connects internal and external factors. Such a perspective may be more comprehensive and systematic, and will be conducive to further enrich existing literatures.

\section{Variable Design, Data Source and Model Construction}

\subsection{Dependent Variable}

The dependent variable of this paper is the corporate social responsibility disclosure (CSRD). Therefore, we refer to the practice of Li and Zhang (2017) and adopts the Rankings CSR Ratings (RKS) to measure the level of corporate social responsibility disclosure.

\subsection{Independent Variables}

1) Goodwill (GW). This paper refers to the practice of Zhou et al. (2019) and standardizes the calculation of goodwill, which is expressed by dividing the net value of goodwill at the end of the year by the total assets at the end of the year.

2) Core management turnover (TURNOVER). The core management personnel refer specifically to the general manager and chairman of the company. According to the statistics on the resignation of the chairman and general manager in the China Stock Market \& Accounting Research (CSMAR) database, if the chairman or general manager of the company changes in the year, it is taken as 1 , otherwise it is taken as 0 .

3) Financing constraints (SA). This paper refers to the research of Sun et al. (2019) and uses the SA index (Size-Age) to measure the financing constraints of a company. A negative SA index and a larger absolute value indicate that the company is subject to more severe financing constraints. The specific calculation method is: $\mathrm{SA}=-0.737 *$ Size $+0.04 * \mathrm{Size}^{2}-0.04$ Age. Among them, Size is the natural logarithm of the size of the company (in million yuan); Age is the time when the company was established.

4) Market competitive position (MP). This paper refers to the practice of Xiao and $\mathrm{Li}$ (2018) and uses (corporate operating income-industry average of operating income)/industry average of operating income to measure market position.

5) Media attention (MEDIA). This paper measures the media attention of enterprises by the sum of paper media reports and network media reports in CNRDS database. This indicator can more comprehensively reflect the media attention than previous measurement indicators.

The above five independent variables correspond to the five hypotheses in the second part of this paper.

\subsection{Control Variables}

In addition to the above five main variables, there are also some secondary fac- 
tors that will affect the level of corporate social responsibility information disclosure. In the follow-up regression treatment, we will control these secondary factors, including: 1) Enterprise size (SIZE): the natural logarithm of total assets. 2) Ownership concentration (FIRST): the proportion of shares held by the largest shareholder. 3) General manager and chairman of the board of directors (DUALI): dummy variable, when the general manager and the chairman of the board are the same person, take 1; otherwise, take 0. 4) Financial leverage (LEV): Asset-liability ratio. 5) Profitability (ROE): Return on Equity.

\subsection{Data Source}

In 2012, China's authoritative social responsibility rating agency RKS adjusted its evaluation method to make it compatible with the international authoritative social responsibility standard ISO60000. We select A-share listed companies that continuously disclose social responsibility information reports in Shanghai and Shenzhen stock markets from 2013 to 2017 as research samples, and conducts the following screening: excluding financial listed companies, ST and ${ }^{*} \mathrm{ST}$ companies, companies with abnormal data (It is mainly caused by the merger and acquisition of the company, the consolidation of financial statements, the reorganization of major assets, the change of accounting standards and etc.) and companies with missing relevant data. Through screening, 2655 company annual observations were finally obtained. In order to eliminate the influence of extreme values, we also tailed the variables. The data in this paper comes from CSMAR, Wind database and financial reports of listed companies.

\subsection{Model Building}

In order to verify the hypothesis 1 to 5 of this paper, we establish model (1) model (5):

$$
\begin{aligned}
& \mathrm{CSRD}_{i, t}=\alpha_{0}+\alpha_{1} \mathrm{GW}_{i, t}+\alpha_{2} \operatorname{SIZE}_{i, t}+\alpha_{3} \operatorname{FIRST}_{i, t}+\alpha_{4} \operatorname{ROE}_{i, t} \\
& +\alpha_{5} \text { DUALITY }_{i, t}+\alpha_{6} \mathrm{LEV}_{i, t}+\varepsilon_{i, t} \\
& \operatorname{CSRD}_{i, t}=\alpha_{0}+\alpha_{1} \text { TURNOVER }_{i, t}+\alpha_{2} \operatorname{SIZE}_{i, t}+\alpha_{3} \operatorname{FIRST}_{i, t}+\alpha_{4} \text { ROE }_{i, t} \\
& +\alpha_{5} \text { DUALITY }_{i, t}+\alpha_{6} \operatorname{LEV}_{i, t}+\varepsilon_{i, t} \\
& \mathrm{CSRD}_{i, t}=\alpha_{0}+\alpha_{1} \mathrm{SA}_{i, t}+\alpha_{2} \mathrm{SIZE}_{i, t}+\alpha_{3} \mathrm{FIRST}_{i, t}+\alpha_{4} \mathrm{ROE}_{i, t} \\
& +\alpha_{5} \text { DUALITY }_{i, t}+\alpha_{6} \operatorname{LEV}_{i, t}+\varepsilon_{i, t} \\
& \mathrm{CSRD}_{i, t}=\alpha_{0}+\alpha_{1} \mathrm{MP}_{i, t}+\alpha_{2} \operatorname{SIZE}_{i, t}+\alpha_{3} \operatorname{FIRST}_{i, t}+\alpha_{4} \operatorname{ROE}_{i, t} \\
& +\alpha_{5} \text { DUALITY }_{i, t}+\alpha_{6} \operatorname{LEV}_{i, t}+\varepsilon_{i, t} \\
& \operatorname{CSRD}_{i, t}=\alpha_{0}+\alpha_{1} \operatorname{MEDIA}_{i, t}+\alpha_{2} \operatorname{SIZE}_{i, t}+\alpha_{3} \operatorname{FIRST}_{i, t}+\alpha_{4} \operatorname{ROE}_{i, t} \\
& +\alpha_{5} \text { DUALITY }_{i, t}+\alpha_{6} \mathrm{LEV}_{i, t}+\varepsilon_{i, t}
\end{aligned}
$$

Before regressing the panel data, this paper conducted F-value test and Husman test. The results show that this paper should choose a fixed-effects model to regress the data. Therefore, we use the individual time-point double fixed effects model to regress the data, and some of the test results will also be displayed in 
the regression results section.

\section{Measurement Inspection Process and Results}

\subsection{Correlation Analysis}

Before the regression analysis, the variables were tested by Pearson correlation. The results show that: 1) goodwill, media attention and market competitive position of enterprises all show a significant positive correlation with the level of corporate social responsibility disclosure, indicating that the higher the corporate goodwill is, the higher the media attention faced by enterprises is, the higher the market competitive position of enterprises is, and the better the level of corporate social responsibility disclosure is. 2) The turnover of core management and the degree of corporate financing constraints are negatively correlated with the level of social responsibility information disclosure, which indicates that the higher the degree of corporate financing constraints is, the lower the level of corporate social responsibility disclosure is. This result initially verified some of the hypotheses in our study. 3) The correlation coefficients between most variables are not more than 0.5 , so there is no serious multi-collinearity problem in this paper.

\subsection{Panel Data Regression Results}

In this paper, the mixed regression model, fixed effect model and random effect model are used to regress the five models, and the F value test and Hausman test are used to test the model. Due to the many steps in the inspection process, it is not fully listed. The results show that the mixed regression model is not applicable in all the regressions in our study. For space reasons, this paper only lists the regression results of the fixed effect and random effect models and the Hausman test results in the table. In the table of regression results, the regression results of each model have two columns, one on the left is the regression results of the fixed effect model, the other on the right is the regression results of the random effect model, and the last is the Hausman test results.

Table 1 is the regression results of goodwill and core management turnover affecting corporate social responsibility disclosure. The last line of the table shows the Hausman test results of model 1 and 2. Since the results are significant at the $1 \%$ level, the null hypothesis is rejected and the random effect model should not be used for regression. Therefore, this paper analyzes the regression results of fixed effect model 1 and 2. It can be seen from the first column of the table that the regression coefficient of corporate goodwill is negative $(-7.268)$, which is consistent with Hypothesis 1, and the result is significant at the 5\% level, indicating that Hypothesis 1 holds that the higher the goodwill is, the lower the level of corporate social responsibility disclosure is. The third column of Table 1 shows the relationship between the turnover of core management, namely general manager and chairman, and the level of social responsibility information disclosure, with a coefficient of -0.400 and significant at $5 \%$ level, indicating that 
Table 1. Model (1) and model (2) regression results.

\begin{tabular}{|c|c|c|c|c|}
\hline \multirow[b]{2}{*}{ VARIABLES } & \multicolumn{2}{|c|}{ (1) } & \multicolumn{2}{|c|}{ (2) } \\
\hline & CSRD & CSRD & CSRD & CSRD \\
\hline & \multicolumn{4}{|c|}{ fixed effect model random effect model fixed effect model random effect model } \\
\hline \multirow[t]{2}{*}{ GW } & $-7.268^{\star *}$ & $-8.788^{\star * *}$ & & \\
\hline & $(-2.40)$ & $(-3.16)$ & & \\
\hline \multirow[t]{2}{*}{ TURNOVER } & & & $-0.400^{* *}$ & $-0.398^{\star *}$ \\
\hline & & & $(-2.13)$ & $(-2.08)$ \\
\hline \multirow[t]{2}{*}{ SIZE } & $1.208^{* *}$ & $2.742^{* * *}$ & $0.969^{*}$ & $2.645^{\star * *}$ \\
\hline & $(2.16)$ & $(8.05)$ & $(1.80)$ & $(7.78)$ \\
\hline \multirow[t]{2}{*}{ FIRST } & 3.620 & $4.843^{* *}$ & $4.206^{*}$ & $5.631^{* * *}$ \\
\hline & $(1.60)$ & $(2.52)$ & $(1.91)$ & $(2.98)$ \\
\hline \multirow[t]{2}{*}{ ROE } & 1.376 & 1.494 & 1.154 & 1.271 \\
\hline & $(0.92)$ & $(1.04)$ & $(0.77)$ & $(0.87)$ \\
\hline \multirow[t]{2}{*}{ DUALITY } & $-0.761^{\star}$ & $-0.704^{\star}$ & -0.626 & -0.588 \\
\hline & $(-1.77)$ & $(-1.68)$ & $(-1.46)$ & $(-1.40)$ \\
\hline \multirow[t]{2}{*}{ LEV } & -0.224 & $-2.355^{\star}$ & -0.199 & -2.307 \\
\hline & $(-0.14)$ & $(-1.66)$ & $(-0.12)$ & $(-1.60)$ \\
\hline \multirow[t]{2}{*}{ CONSTANT } & $27.257^{\star \star *}$ & $13.664^{* * *}$ & $29.252^{\star * \star}$ & $14.247^{\star * *}$ \\
\hline & $(5.44)$ & $(4.86)$ & $(6.00)$ & $(5.05)$ \\
\hline Observations & 2654 & 2654 & 2654 & 2654 \\
\hline Number of com & 531 & 531 & 531 & 531 \\
\hline Adj-R-squared & 0.106 & & 0.105 & \\
\hline Company FE & YES & NO & YES & NO \\
\hline Year FE & YES & YES & YES & YES \\
\hline Hausman test & \multicolumn{2}{|c|}{ Prob $>$ chi $^{2}=0.0000$} & \multicolumn{2}{|c|}{ Prob $>$ chi $^{2}=0.0000$} \\
\hline
\end{tabular}

Note: ${ }^{* *},{ }^{* *}$ and ${ }^{*}$ denote significance at $1 \%, 5 \%$ and $10 \%$ levels, respectively.

corporate social responsibility disclosure will decrease when core executives change, which is consistent with hypothesis 2 .

Table 2 reflects the regression results of financing constraints, market competitive position, media attention and corporate social responsibility disclosure. The last line of the table shows the Hausman test results of model 3, 4 and 5. Since the results are significant at the $1 \%$ level, the null hypothesis is rejected and the random effect model should not be used for regression. Therefore, we analyze the regression results of the fixed effect models of model 3, 4 and 5. The first column shows that the coefficient of financing constraints (SA) is -10.223 and is significant at $1 \%$ level. This shows that financing constraints (SA) and corporate social responsibility disclosure is significantly negatively correlated, hypothesis 3-2 is tested, which reflects that when domestic enterprises face 
Table 2. Model (3) - model (5) regression results.

\begin{tabular}{|c|c|c|c|c|c|c|}
\hline \multirow[b]{2}{*}{ VARIABLES } & \multicolumn{2}{|c|}{ (1) } & \multicolumn{2}{|c|}{ (2) } & \multicolumn{2}{|c|}{ (3) } \\
\hline & CSRD & CSRD & CSRD & CSRD & CSRD & CSRD \\
\hline & $\begin{array}{c}\text { fixed effect } \\
\text { model }\end{array}$ & $\begin{array}{l}\text { random } \\
\text { effect model }\end{array}$ & $\begin{array}{c}\text { fixed effect } \\
\text { model }\end{array}$ & $\begin{array}{l}\text { random } \\
\text { effect model }\end{array}$ & $\begin{array}{l}\text { fixed effect } \\
\text { model }\end{array}$ & $\begin{array}{l}\text { random } \\
\text { effect model }\end{array}$ \\
\hline \multirow[t]{2}{*}{ SA } & $-10.223^{* * *}$ & $-9.049^{* * *}$ & & & & \\
\hline & $(-3.01)$ & $(-6.03)$ & & & & \\
\hline \multirow[t]{2}{*}{ MP } & & & 0.078 & $0.200^{* *}$ & & \\
\hline & & & $(0.51)$ & $(2.02)$ & & \\
\hline \multirow[t]{2}{*}{ MEDIA } & & & & & $0.438^{*}$ & $0.749^{* * *}$ \\
\hline & & & & & $(1.95)$ & $(4.08)$ \\
\hline \multirow[t]{2}{*}{ SIZE } & 0.523 & $1.850^{\star * *}$ & $0.922^{*}$ & $2.514^{\star * \star}$ & $0.930^{*}$ & $2.412^{* * *}$ \\
\hline & $(0.89)$ & $(5.52)$ & $(1.72)$ & $(7.31)$ & $(1.72)$ & $(9.26)$ \\
\hline \multirow[t]{2}{*}{ FIRST } & $4.042^{*}$ & $4.261^{* *}$ & $4.104^{*}$ & $5.590^{* * *}$ & $4.274^{*}$ & $5.704^{* * *}$ \\
\hline & $(1.86)$ & $(2.33)$ & $(1.87)$ & $(2.98)$ & $(1.96)$ & $(3.47)$ \\
\hline \multirow[t]{2}{*}{ ROE } & 1.572 & 1.792 & 1.300 & 1.418 & 0.894 & 0.695 \\
\hline & $(1.05)$ & $(1.25)$ & $(0.86)$ & $(0.97)$ & $(0.58)$ & $(0.53)$ \\
\hline \multirow[t]{2}{*}{ DUALITY } & $-0.730^{\star}$ & $-0.700^{\star}$ & $-0.743^{*}$ & $-0.702^{*}$ & $-0.738^{*}$ & $-0.701^{\star}$ \\
\hline & $(-1.66)$ & -1.65 & $(-1.74)$ & $(-1.68)$ & $(-1.72)$ & $(-1.90)$ \\
\hline \multirow[t]{2}{*}{ LEV } & 0.191 & -1.197 & -0.139 & -2.310 & -0.232 & $-2.289^{\star}$ \\
\hline & $(0.12)$ & -0.85 & $(-0.08)$ & $(-1.60)$ & $(-0.14)$ & $(-1.90)$ \\
\hline \multirow[t]{2}{*}{ CONSTANT } & $71.146^{* * *}$ & $55.104^{\star * *}$ & $29.519^{* * *}$ & $15.150^{\star * *}$ & $27.015^{\star * *}$ & $12.013^{* * *}$ \\
\hline & $(4.94)$ & $(7.98)$ & $(6.11)$ & $(5.34)$ & $(5.30)$ & $(5.21)$ \\
\hline Observations & 2654 & 2654 & 2654 & 2654 & 2654 & 2654 \\
\hline Number of com & 531 & 531 & 531 & 531 & 531 & 531 \\
\hline Adj-R-squared & 0.112 & & 0.104 & & 0.106 & \\
\hline Company FE & YES & NO & YES & NO & YES & NO \\
\hline Year FE & YES & YES & YES & YES & YES & YES \\
\hline Hausman test & \multicolumn{2}{|c|}{ Prob $>$ chi $2=0.0007$} & \multicolumn{2}{|c|}{ Prob $>$ chi $2=0.0000$} & \multicolumn{2}{|c|}{ Prob $>$ chi $2=0.0000$} \\
\hline
\end{tabular}

Note: ${ }^{* *},{ }^{* *}$ and ${ }^{\star}$ denote significance at $1 \%, 5 \%$ and $10 \%$ levels, respectively.

higher financing constraints, they will not release financing constraints by disclosing corporate information including social responsibility information according to traditional views. Enterprises may broaden their financing channels by expanding their scale and holding banks, so as to alleviate the financing constraints.

The results of the third column show that the coefficient of market competitive position (MP) is 0.078 , indicating that market competitive position has a positive impact on corporate social responsibility disclosure, but this result is not significant, hypothesis 4 has not been verified. This may be because, due to the 
differences among industries, although some enterprises are in a dominant position in the industry, the industry as a whole is gradually weakening. Even if the leading enterprises in the industry have great survival pressure, they cannot invest resources to fulfill their social responsibility and improve the level of disclosure of social responsibility information. The fifth column of Table 2 shows the regression results of media attention (MEDIA) and corporate social responsibility information disclosure. The results show that the coefficient of media attention (MEDIA) is 0.438 , and it is significant at the level of $10 \%$, which indicates that the higher the degree of media attention, the higher the level of corporate social responsibility disclosure. This conclusion verifies the hypothesis 5 .

To sum up, among the five research hypotheses, hypothesis 1, 2, 3-2 and 5 are valid, while hypothesis 3-1 and 4 are not verified.

\section{Conclusion and Recommendation}

\subsection{Conclusion}

On the basis of theoretical analysis, we collect the panel data of A-share listed companies that continuously disclose social responsibility reports from 2013 to 2017 in China, and explore the influence of goodwill, core management turnover, financing constraints, market competitive position and media attention on the level of corporate social responsibility disclosure. The results show that goodwill, core management turnover, and financing constraints all have a significant negative correlation with corporate social responsibility disclosure. Media attention has a significant positive impact on the level of corporate social responsibility disclosure; corporate market position has no significant impact on social responsibility information disclosure.

\subsection{Recommendation}

From the current practice of Chinese enterprises, there are problems such as relatively weak awareness of corporate social responsibility, imperfect system, poor performance of corporate social responsibility, and low quality of disclosure reports. In order to solve these problems, this paper puts forward the following suggestions. Firstly, in order to combine the incentive policies of executives with the long-term development of enterprises, enterprises should conduct a comprehensive evaluation from the aspects of executives' competence, organizational culture construction, formulation and implementation of enterprise development strategies and current performance, so as to avoid arbitrary changes of executives. Secondly, it should promote the healthy development of the media industry and stop the rent-seeking behavior of news agencies. Thirdly, enterprises should be encouraged to undertake social responsibility, integrate the disclosure of social responsibility information into the corporate culture, further strengthen the awareness of corporate social responsibility and improve the disclosure mechanism of social responsibility information. Finally, the barriers to financing channels should be broken as soon as possible to avoid unfair competition in fi- 
nancing caused by political connection factors.

\section{Conflicts of Interest}

The authors declare no conflicts of interest regarding the publication of this paper.

\section{References}

Deng, K. B., \& Zeng, H. J. (2014). The Financial Constraints in China. Economic Research Journal, 49, 47-60+160.

Gillan, S. L., Koch, A., \& Starks, L. T. (2021). Firms and Social Responsibility: A Review of ESG and CSR Research in Corporate. Journal of Corporate Finance. https://doi.org/10.1016/j.jcorpfin.2021.101889

Gu, L. L., Guo, J. L., \& Wang, H. Y. (2020). Corporate Social Responsibility, Financing Constraints, and the Financialization of Enterprises. Journal of Financial Research, No. 2, 109-127.

Huang, Q. H., Zhong, H. W., \& Zhang, E. (2019). Research Report on Corporate Social Responsibility of China (p. 11). Beijing: Social Sciences Academic Press (China).

Li, Z. B., \& Zhang, T. S. (2017). Internal Control, Nature of Property Right and Social Responsibility Information Disclosure: Evidence from Chinese Listed Companies. Accounting Research, No. 10, 86-92+97.

Nan, X. H., \& Sun, X. X. (2020). Controlling Shareholder's Equity Pledge, Corporate Social Responsibility and Real Earnings Management. Investment Research, 39, 60-76.

Sun, X. J., Zhai, S. P., \& Yu, S. (2019). Can Flexible Tax Enforcement Ease Corporate Financing Constraints-Evidence from a Natural Experiment on Tax-Paying Credit Rating Disclosure. China Industrial Economics, No. 3, 81-99.

Tseng, C.-Y., \& Demirkan, S. (2021). Joint Effect of CEO Overconfidence and Corporate Social Responsibility Discretion on Cost of Equity Capital. Journal of Contemporary Accounting \& Economics, 17, Article ID: 100241. https://doi.org/10.1016/j.jcae.2020.100241

Xiao, H. J., \& Li, J. L. (2018). The Dynamic Test of Iron Law of Responsibility: Empirical Evidence from the M\&A Samples of Chinese Listed Companies. Management World, 34, 114-135.

Xu, J. C., Zhang, D. X., \& Liu, H. H. (2017). Does Purchased Goodwill Information Affect the Cost of Debt? Journal of Central University of Finance \& Economics, 3, 109-118.

Yang, W., Song, M., \& Feng, K. (2018). M\&A Goodwill, Investor Overreaction, and Stock Price Bubbles and Crashes. China Industrial Economics, No. 6, 156-173.

Yu, Y., \& Chi, J. (2021). Political Embeddedness, Media Positioning and Corporate Cocial Responsibility: Evidence from China. Emerging Markets Review. https://doi.org/10.1016/j.ememar.2021.100799

Yuan, L. P. (2020). Research on the Construction of Soft Law for Corporate Social Responsibility Information Disclosure. Review of Political Science and Law, No. 2, 149-160.

Zhang, J. X., Cai, Y. D., \& Ni, G. Q. (2019). The Effect of Disclosure Tone of Corporate Social Responsibility and Disclosure Integrity of Financial Information on Investors' Perceived Fulfillment of Corporate Social Responsibility: An Experimental Research. Nankai Business Review, 22, 206-212+224.

Zhou, Z. J., Hu, L. F., Ma, J., \& Zhang, D. X. (2019). Goodwill and Corporate Risk-Taking. Accounting Research, No. 7, 21-26. 